\title{
NATIONAL BUSINESS CULTURES: RESEARCH METHODOLOGY, CONTENT AND ROLE IN PROVISION OF INTERNATIONAL ENTREPRENEURSHIP
}

Formulation of the problem. Analysis and systematization of economic facts, phenomena and developmental trends of large organizations (enterprises; institutions; public, religious and political organizations, etc.), individual countries and international institutions gives theoretical and practical reasons to note that many modern economic problems are largely predetermined by the nature and characteristics of national business cultures of various countries.

Thus, the complex interdisciplinary cognitive and applied problem of comparative cross-cultural (intercultural) studies arises, the basis of which is research in the economic sphere - the development of systemic knowledge about the content, forms of manifestation of national business cultures and the use of acquired knowledge in international entrepreneurship.

The basis of such studies is clarification of the methodological aspects of the development of this interdisciplinary problem.

The level of development of the problem and its least investigated aspects. The problem of national business cultures is not sufficiently developed. This is common to all countries however, in particular, this situation is characteristic of Ukraine and other countries of the former USSR: scientific researches on this topic are extremely few. To a certain extent, this originates from the insufficient involvement of business structures in the system of the international division of labor.

Herewith, issues of cross-cultural management are considered to a somewhat greater extent $[1 ; 2 ; 3]$. Valuable significance demonstrates the analysis of ethnomanagement [4]. The first attempts were made to analyze the problems and prospects of joint activities of domestic entrepreneurs together with businessmen from other countries in the markets of third countries $[5 ; 6]$.

The main disadvantage of domestic studies of this problem, which is also typical for authors of other countries, is the lack of a systematic approach. This is predetermined by insufficient attention to the development of initial methodological aspects. Also, the connection between existing developments and the real business practices of modern business is poorly traced.

The purpose of the article is to analyze and generalize the evolution of the formation of scientific knowledge of national business cultures, the identification of the definition of "national business cultures" and the disclosure of its essential content.
Statement of the main material. At the source of the formation of scientific and practical knowledge of national business cultures was a famous scientist, manager and practitioner from the Netherlands G. Hofstede $[7 ; 8]$. In Western science, for his convincing contribution to the development of this problematics, which he began to study in the sixties and seventies of the last century, he is singled out as one of the hundred most outstanding managers. Somewhat later, this kind of scientific and practical development of these issues was carried out by another outstanding representative of the Netherlands - F. Trompenaars $[9 ; 10]$.

Due to its objective relevance in the eighties and nineties, the studies of this problematics were embodied in rather large-scale developments in various branches of economic science (although the predominant part of them was devoted specifically to managerial aspects). This became the basis for highlighting a new direction in economics - comparative studies.

Economic comparative studies arose as a comparative - cross-cultural management. The followers of G. Hofstede and F. Trompenaars in the study of managerial aspects of national business cultures (they remain the most developed in modern conditions in all countries) are R. Gill and A. Wong, H. Deresky, R. Lessem and F. Neubauer.

In the nineties, systemic developments took place in another area of research on national business cultures - cross-cultural communications. Their purpose was to clarify the peculiarities of communicative behavior and interaction of representatives of different countries and cultures in business and public sectors. The most authoritative representative of cross-cultural communications research is a famous English scientist, practitioner and business trainer R. Lewis [11; 12]. A notable contribution to communication research in the field of international entrepreneurship also made M. Guirdham, M. Limaye and D. Victor.

Especially intensively at the beginning of the XXI century a marketing aspects of national business cultures began to be developed and formed as an independent research area. In economic comparative studies, it can be entitled as cross-cultural marketing. As representatives of this trend can be outlined W. Keegan, J.-C. Usunier, N. Holden. It seems that in the upcoming years cross-cultural marketing will attract more and more attention not only from theoretical scientists, but also from practitioners. 
The most productive and original in the marketing approach are the designs of C. Rapaille (French by nationality and American by his current citizenship) [13; 14]. They are based on the analytical psychology of Carl Jung and, in particular, on the psychoanalysis of Sigmund Freud with the subsequent transfer of analysis to the sphere of economic behavior of consumers.

An analysis of the evolution of the emergence and development of the theory of national business cultures leads to the need to identify three major areas within it: managerial, communicative and marketing. Theoretical and practical developments in these areas were carried out and are being carried out in modern conditions (which cannot be noted in relation to Ukraine) quite intensively. Naturally, the identified areas took shape in relatively independent branches of scientific and practical research.
Managerial approach in developing national business cultures took shape as cross-cultural management. Communicative approach - as cross-cultural communication. Marketing approach got materialized as crosscultural marketing.

Accordingly, independent educational disciplines began to be introduced at leading universities in Europe and the world: "Cross-cultural management", "Crosscultural communications", "Cross-cultural marketing” (very often not only entrepreneurship, but also public sector and non-profit realm becomes the sphere of analysis).

The analysis of the classification of methodological approaches in the study of national business cultures and the characteristics of these approaches on the example of their most authoritative representatives are reflected in Table.

Methodological approaches to the study of national business cultures*

\begin{tabular}{|c|c|}
\hline $\begin{array}{l}\text { Classification } \\
\text { of approaches }\end{array}$ & Generalized characteristic of approaches \\
\hline Managerial & $\begin{array}{l}\text { Characterization of national business cultures based on the allocation of two-dimensional parameters } \\
\text { ("individualism”, "power distance”, "masculinity", "uncertainty avoidance”, "Confucian dynamism”) } \\
\text { with their subsequent consideration within the system "Family - School - Work” (G . Hofstede) }\end{array}$ \\
\hline Communicative & $\begin{array}{l}\text { Characterization of national business cultures using two types of psychological behavior (introverts - } \\
\text { extroverts) and three-dimensional characteristics of entrepreneurial activity (linear activity, reactivity, } \\
\text { polyactivity) with the subsequent construction of triangles and placement on its base and legs countries } \\
\text { and their groups of 2-4 (R. Lewis) }\end{array}$ \\
\hline Marketing & $\begin{array}{l}\text { Characterization of national business cultures on the basis of identifying the most typical consumer } \\
\text { strata in the frames of individual countries and describing the cultural codes of countries by disclosing } \\
\text { the contents of the selected triad "Logical Emotionality" - "Archetype" - "Cultural Code" (C Rapaille) }\end{array}$ \\
\hline
\end{tabular}

* Own author's elaboration.

The conducted analysis gives theoretical and practical reasons to identify the definition of "national business cultures" (which researchers do not pay due attention to).

National business cultures are a system of intrinsic, evolutionarily formed and reproduced in space and time basic value orientations of entrepreneurial activity; its behavioral canons, norms and traditions of implementation, as well as stereotypes, attributes and business ethics of doing business that are characteristic of a particular country (groups of countries similar in their respective essential parameters).

The category "national business cultures" reflects the totality of multilevelled nature: phenomena, processes and developmental trends. This is the main essential feature of this definition. It seems appropriate (necessary and sufficient) in the aggregate of phenomena, processes and development trends, reflected by the definition of "national business culture" to identify three areas (levels).

The internal sphere of national business culture, acting as its peculiar core, is a structured system of basic (fundamental) provisions of entrepreneurial activity, laying the essential foundations for the formation and main mechanisms for the implementation of the business culture of a country. This system of basic provisions and the main mechanisms is embodied first in the aggregate of managerial relations, and then in the external forms of their support (in the practical implementation of entrepreneurial activity).

The distinguished internal sphere of national business cultures predetermines their intermediate sphere.

The intermediate sphere of national business culture is the combination of its most characteristic motives and behavioral norms for entrepreneurs of a country in the creation and implementation of a business.

A set of factors of the intermediate environment of national business culture is embodied in varying degrees of technocratism of managers and administrators; their predominant propensity for group initiative; informal procedures; assertiveness in achieving commercial interests of organization and independence of making personal career. In addition, they manifest themselves in varying degrees of adaptation to adverse economic and, in particular, institutional factors; ability to get out of conflict situations and recover from inevitable stressful psychological tensity that accompanies real business activity. 
The intermediate sphere of national business cultures, acting as a function of the corresponding internal sphere, in its turn, determines the external sphere.

The external sphere of national business culture is a set of rules-standards of business ethics and business etiquette, characteristic of entrepreneurs of a particular country, norms and canons of cross-cultural communications. They include procedures for the justification and submission of documents on entrepreneurial activities; techniques for the preparation, conduct of commercial negotiations and conclusion of transactions; existing stereotypes and taboos observed in the practical implementation of entrepreneurship in different cultures and countries; tools for the preparation and presentation of presentations. This also includes the dress code of the leading national business structures of a country (if we are not talking about specific strictly defined business structures of a country, such rules and standards are not recorded in documents of a regulatory nature).

The basis of the phenomena and processes reflected in the category of "national business culture" is the economic sphere. The complex of these phenomena and processes, by their internal nature, is a product of the economy as such. This is a combination of managerial relations and relations arising at the meeting point of management with marketing, management with finance, management with the economy, as well as management with public relations. Therefore, national business culture reflects the complex of relations internally inherent in entrepreneurship. This indicates them as economic relations in their essential nature.

At the same time, the formation and, in particular, the external manifestation of these relations, is greatly affected by the totality of the vital factors of modern society: institutional, international, demographic, psychological, and natural (including scientific and technical).

For quantitative analysis and generalized assessments of national business cultures in modern conditions, as a rule, the following parameters are used:

- "Power distance";

- "Individualism";

- "Masculinity";

- "Uncertainty avoidance";

- "Long-term orientation";

- "Indulgence".

These measuring instruments are used in the developments of an authoritative center for the study of national business cultures - Hofstede Insights, licensed by G. Hofstede [15].

These measuring instruments and parameters act as a sort of synthesis (sufficiently reasoned and successful) of the theories of G. Hofstede and F. Trompenaars. At the same time, the parameter estimation toolkit is used, which is typical for the methods of both authors: an assessment of their extreme values from lowest to highest with a quantitative indicator for each country.
Paying respect to the developments of G. Hofstede and F. Trompenaars, as well as their followers, we consider it necessary to note the following.

These developments and assessments are principally based on theoretical studies conducted mainly in the eighties and nineties of the XIX century. Meanwhile, in the late XIX and early XX centuries, numerous dramatic changes took place in the economic, institutional and scientific-technical spheres. First of all, a post-industrial society began to develop on its own. The introduction of information technologies in the production and commercial process and, as a whole, in the life of society became widespread. Further: in the presented studies of national business cultures, the problems of small and medium-sized businesses largely fell out of sight; including - new approaches of the European Union to its regulation.

Conclusions. In national economic science, the problematics of national business cultures has not yet become the subject of systematic theoretical, and even more so, applied practical developments. This objectively influences the effectiveness of international entrepreneurial activity of Ukrainian business structures. In particular, the development of normative legislative acts in the relevant sphere of state regulatory policy.

Prospects for further studies of the analyzed problem. Further studies of national business cultures should be carried out taking into account the complex of economic, natural and institutional changes that are characteristic of modern conditions and projected developmental trends.

\section{Literature}

1. Бондаренко Н. Пять камней преткновения эффективной кросс культурной коммуникации. URL: http://blogtrenera.ru/blog/pyat-kamnej-pretknoveniya-ef fektivnoj-kross-kulturnoj-kommunikacii.html. DoA: 30.11.2019. 2. Пивоваров С.Э., Максимцев И.А. Сравнительный менеджмент. 2-е изд. СПб.: Питер, 2008. 480 с. 3. Тодорова Н.Ю. Кроскультурний менеджмент. Донецьк : ДонНТУ, 2008. 330 с. 4. Павлов К. В. Этноменеджмент и этноэкономика. Економічний вісник Донбасу. 2016. № 1(43). С. 131-141. 5. Glinkowska B., Chebotarov V. A Comparative CrossCultural Analysis of the Profile of a Modern Ukrainian Manager: the Imperatives of the Future in the Context of Internationalization. Comparative Economic Research. 2018. Vol. 21. № 3. C. 63-74. doi: 10.2478/cer-2018-0019.

6. Glinkowska B., Chebotarov V. Establishing a business in Ukraine - the Initial regulatory organizational and legal aspects for Polish entrepreneurs. Comparative Economic Research. 2019. Vol. 22. № 1. C. 75-86. doi: https://doi.org/10.2478/cer-2019-0005. 7. Hofstede G. Culture's consequences: International differences in work-related values. Beverly Hills, CA: Sage Publications, 1980. 328 p. 8. Hofstede G. Culture's consequences: Comparing values, behaviors, institutions and organizations across nations (second edition). Thousand Oaks : Sage Publications, 2001. 616 p. 9. Trompenaars F. Riding 
the waves of culture: Understanding cultural diversity in business. London: Economist Books, 1993. 208 p. 10. Hampden-Turner C., Trompenaars F. The seven cultures of capitalism: Value systems for creating wealth in the United States, Britain, Japan, German, France, Sweden and the Netherlands. London : Little, Brown Book Group, 1995. 416 p. 11. Lewis R. Cross Cultural Communication: A Visual Approach, Transcreen Publications, 2008. 287 p. 12. Lewis R.D. When Cultures Collide: Managing successfully across cultures, 3nd ed, Nicholas Brealey Publishing, 1999. 336 p. 13. Rapaille C. 7 Secrets of Marketing in a Multi-Cultural World, 2nd ed, Tuxedo Production, 2004. 318 p. 14. Rapaille C. The Culture Code, Broadway Books, 2007. 213 p. 15. Hofstede Insights. URL: https://www.hofstede-insights.com/models /national-culture/ DoA: 30.11.2019.

\section{References}

1. Bondarenko N. Pyat' kamney pretknoveniya effektivnoy kross kul'turnoy kommunikatsii [Five stumbling-stones to effective cross-cultural communication]. Retrieved from http://blogtrenera.ru/blog/pyat-kamnejpretknoveniya-effektivnoj-kross-kulturnoj-kommunikacii.html [in Russian]. DoA: 30.11.2019.

2. Pivovarov S.E., Maksimtsev I.A. (2008). Sravnitel'nyy menedzhment [Comparative management]. 2-e izd. SPb., Piter [in Russian].

3. Todorova N.Ju. Kroskulturnyi menedzhment [Cross Cultural Management]. Donetsk, DonNTU, 2008 [in Ukrainian].

4. Pavlov K. V. (2016). Etnomenedzhment i etnoekonomika [Ethnic management and ethnoeconomics]. Ekonomichnij visnik Donbasu [Economic Herald of the Donbas], 1(43) [in Russian].

5. Glinkowska B., Chebotarov V. A. (2018). Comparative Cross-Cultural Analysis of the Profile of a Modern Ukrainian Manager: the Imperatives of the Future in the Context of Internationalization. Comparative Economic Research, 3. Vol. 21. doi: 10.2478/cer-2018-0019.

6. Glinkowska B., Chebotarov V. (2019). Establishing a business in Ukraine - the Initial regulatory organizational and legal aspects for Polish entrepreneurs. Comparative Economic Research, 1. Vol. 22. doi: https://doi.org/ 10.2478/cer-2019-0005.

7. Hofstede G. (1980). Culture's consequences: International differences in work-related values. Beverly Hills, CA, Sage Publications.

8. Hofstede G. (2011). Culture's consequences: Comparing values, behaviors, institutions and organizations across nations (second editions). Thousand Oaks, Sage Publications.

9.Trompenaars F (1993). Riding the waves of culture: Understanding cultural diversity in business. London, Economist Books.

10. Hampden-Turner C. and Trompenaars F. (1994). The seven cultures of capitalism: Value systems for creating wealth in the United States, Britain, Japan, German, France, Sweden and the Netherlands. London, Juli Piatkus.

11. Lewis R. (2008, 1999). Cross Cultural Communication: A Visual Approach, Transcreen Publications.
12. Lewis R.D. (2005). When Cultures Collide: Managing successfully across cultures. 3rd ed. Nicholas Brealey Publishing.

13. Rapaille, C. (2004). 7 Secrets of Marketing in a Multi-Cultural World. 2nd ed. Tuxedo Production.

14. Rapaille, C. (2007). The Culture Code, Broadway Books.

15. Hofstede Insights. Retrieved from https://www. hofstede-insights.com/models/national-culture/ DoA: 30.11.2019.

Чеботарьов С. В. Національні ділові культури: методологія дослідження, зміст і роль в забезпеченні міжнародного підприємництва

Об'єктом аналізу є сукупність методологічних положень економічної компаративістики: дослідження національних ділових культур. Усвідомлюється еволюція менеджерського, комунікативного та маркетингового підходів в їх розгляді. Обгрунтовується дефініція “національні ділові культури” і розкриваються сутнісні явища, процеси і тенденції розвитку, які в ній відображаються.

Ключові слова: економічна компаративістика, національні ділові культури, крос-культурний менеджмент, крос-культурні комунікації, крос-культурний маркетинг.

Chebotarov Ie. National Business Cultures: Research Methodology, Content and Role in Provision of International Entrepreneurship

The object of analysis is a complex of methodological principles of economic comparative studies: the studies of national business cultures. The evolution of managerial, communicative and marketing approaches in their consideration is being comprehended. The definition of "national business cultures" is substantiated and the essential phenomena, processes and developmental trends that are reflected in the definition are revealed.

Keywords: economic comparative studies, national business cultures, cross-cultural management, cross-cultural communications, cross-cultural marketing.

Чеботарев Е. В. Национальные деловые культуры: методология исследования, содержание и роль в обеспечении международного предпринимательства

Объектом анализа является совокупность методологических положений экономической компаративистики: исследование национальных деловых культур. Осознается эволюция менеджерского, коммуникативного и маркетингового подходов в их рассмотрении. Обосновывается дефиниция "национальные деловые культуры" и раскрываются сущностные явления, процессы и тенденции развития, которые в ней отражаются.

Ключевые слова: экономическая компаративистика, национальные деловые культуры, кросс-культурный менеджмент, кросс-культурные коммуникации, кросс-культурный маркетинг.

Received by the editors: 02.12 .2019

and final form 19.12.2019 